\title{
'Bildung' in German human sciences: the discursive transformation of a concept
}

\author{
Julian Hamann, University of Bamberg
}

\begin{abstract}
This article analyses the transformation of the notion of Bildung that is constructed in the German human sciences. From a perspective of field theory and discourse analysis, the article reveals how the notion evolves and stabilizes during a first stage (1810-60), how it comes under pressure because of the contextual changes in a second stage (1860-1960) and how the tension increases before it is resolved by a fundamental change of the traditional notion of Bildung in a third stage (1960-99).
\end{abstract}

\section{Introduction}

How can we grasp the relationship between ideas and contexts? How do concepts change in relation to the altering circumstances they are produced and received in? The aim of this article is to put forward an answer to these questions by means of an empirical example. A historical exploration, led by Bourdieu's field theory and discourse analysis, traces the transformation of the notion of Bildung ${ }^{1}$ that is constructed discursively in the field of German human sciences ${ }^{2}$ and relates it to a selection of contextual factors that are crucial in this process. The main part of the article describes the development in the discourse about Bildung in three formative stages. To this end, the specific material and symbolic contextual factors that form a framework for the struggles over Bildung are examined in each case. The concluding remarks put the insights that have been provided by the empirical example into a broader context and relate them to the questions that have been posed at the beginning. The article starts off with a brief overview of the methodological and empirical premises guiding the examination.

Since the very beginning of their existence as a disciplinary group, the German human sciences have bred a whole literary genre concerned with the state they are in - needless to say this has

\footnotetext{
${ }^{1}$ There is no direct translation for the German term Bildung, and the variation of the concept's meaning over time is the very matter of this article. What seems to be beyond dispute over a long period of time is that Bildung covers a form of self-cultivation and learnedness, embracing the whole personality of the individual. The formed or valuesaturated personality is attained by understanding and experiencing general cultural values (more successful attempts at translating the traditional concept can be found in Ringer, 1989; Sorkin, 1983). However, by and by this notion has been transformed into a notion of Bildung that is closer to vocational training than to selfcultivation, providing a certain set of skills rather than aiming at the whole personality and teaching practical abilities and competencies rather than passing on general cultural values. This article aims at the scientific notion of the concept of Bildung, leaving out its relevance for primary and secondary education.

${ }^{2}$ Just like the term Bildung, Geisteswissenschaften is another concept that is difficult to translate as it has no direct equivalent in other languages. The term has its roots in the Romantic, idealistic and neo-humanistic climate of late 18th- and early 19th-century Germany, when on philological, philosophical and historical disciplines - that up until today form the core of the disciplinary group - was conferred the status of sciences. The constitutional moment of the Geisteswissenschaften was when the merely propaedeutic occupation with classical languages was superseded by research, led by an impetus to scientifically analyse the spirit (Geist) of the Greeks, who were deemed to be kindred with the philosophical nation that was Germany (concise descriptions of the term and origin of the Geisteswissenschaften can be found in Diemer, 1974; Geldsetzer, 1974; Rüegg, 2004). Throughout the text, 'human sciences' will be used as a translation of the term.
} 
almost always been a state of crisis. A pivotal topic of this discursive context is the reflection about the legitimate notion of Bildung. While the label itself has been ever-present in the selfconception of the disciplinary group, its very meaning is subject to the interpretational efforts taking place in the human sciences. The notion is generated in the field's specialist discourse and, at the same time, it generates the agents' practice in this context. As both a structuring and structured structure of knowledge (cf. Bourdieu, 1991: 164-6), the respective dominant construction of Bildung possesses an especially high capacity of structuration in the selfreflective discourse of the field of human sciences, because the disciplinary group is (held) responsible for the definition and preservation of a national cultural canon. ${ }^{3}$

Against the background of Bourdieu's field theory, the discursive construction of Bildung can be understood as a symbolic struggle. The subjects of these struggles are definitions of positions that can be taken, as well as of resources that can be acquired in the field. In other words, '[w] hat is at stake in the symbolic struggle is the monopoly of legitimate nomination, the dominant viewpoint which, in gaining recognition as the legitimate viewpoint, causes its truth as a specific, situated, dated viewpoint to be misconstrued' (Bourdieu, 1988: 26). Different constructions of Bildung are but one exemplary result of the symbolic struggles taking place in the field.

The agents' interpretations and attributions unfurl in a material context that presents itself as a structure of available resources. The respective allocation of these resources marks a space of possibilities in which knowledge can be produced and received. In the following, this material structure of the field of German human sciences is being considered with two indicators. First, the indicator population embraces the number and the social background of the students as well as the mode of recruitment of the professors. Second, the indicator institutional differentiation draws attention to the structure of subjects in German human sciences as an organizational frame of the development. However, shape and outcome of symbolic struggles are not only influenced by the availability or scarcity of material resources that is captured rudimentarily by the two indicators above. The actors' struggles are also framed by a symbolic structure, understood as common ascriptions and knowledge that is widely acknowledged in the discourse and that is taken into account during those efforts. The study approaches this symbolic frame with the indicator notion of science. ${ }^{4}$ Generally speaking, statements about this notion establish the respective standards for the scientific character of the disciplines. Hence, they are a fundamental part of the discursive self-reflection of German human sciences. Furthermore, the dominant notion of science has a high capacity of structuration for the practice in the whole field, not least because of the unity of research and teaching (Einheit von Forschung und Lehre).

\footnotetext{
${ }^{3}$ Ringer (1990: 87) emphasizes that the importance of this concept goes beyond the academic field of German human sciences: 'The word Bildung, as it evolved during the late eighteenth century, contained the single most important tenet of the mandarin tradition.'

${ }^{4}$ The term Wissenschaft is a prominent example of the close relation of a concept's meaning and its context. A specific trait of the German term Geisteswissenschaften is that the disciplines included in it are still very much residing in the area of science. In this regard, there has never been a clear distinction between arts and human sciences on the one side and science on the other side, which is the common systematization in probably most other western countries. Science in the German sense of Wissenschaft covers any systematic inquiry. English readers of this article will have to bear this in mind, because the remarks about the notion of science that can be found in the following are always meant as a reference to science in the German sense. The common scientific ground that Geisteswissenschaften and Naturwissenschaften are sharing is going to form the foundation for fierce competition later on. Right now, it is sufficient to consider that the notions and standards that are ascribed to the practice in German human sciences have a scientific character that is - at least in principle - comparable to the notion of science in force in every other scientific field.
} 
The three indicators - population, institutional differentiation and notion of science - give a rough idea of the context in which the production and reception of the concept of Bildung are taking place. By capturing a structure of allocation of material resources with the first two indicators alongside a structure of interpretation of symbolic resources with the third indicator, we are able to take into account the two dimensions Bourdieu ascribes to the reality of fields.

The historical examination starts off when the disciplinary identity of German human sciences emerges at the beginning of the 19th century. Up until the end of the 18th century, the faculty of philosophy served as some kind of preparatory school for the other faculties, imparting a general education (Allgemeinbildung) that was meant to prepare for studies in jurisprudence, medicine, or theology. It was not until the professionalization of the education of teachers that the transformation from the handmaid of the higher faculties (cf. Kant, 1977: 228; 2005: 28) to the "first and indeed mistress of all others' ${ }^{5}$ (Schleiermacher, 1956: 260) took place. The change in the balance of power between the faculties was fully institutionalized when Humboldt founded the University of Berlin in 1809. From then on, the new ethos of the university was determined not by religious prejudice or the utilitarian-professional functions of the former higher faculties, but by knowledge for the sake of knowledge. The realization of the then emerging notion of Bildung, based on neo-Humanism and the philosophy of German Idealism, puts the ennoblement of the character not only into the centre of Bildung in the human sciences, but also into the centre of the development of the German university as a whole. As a consequence, the faculty of philosophy is destined to be the institutional hub of this transformation, and it is becoming the institutional and ideological centre in most newly established universities from then on. The occupation with Allgemeinbildung, formerly demoting the faculty to a mere accessory of the higher faculties, has become an advantage in Der Streit der Fakultäten [The Conflict of the Faculties] (Kant, 2005). ${ }^{6}$

\section{First stage, 1810-60}

\section{Material and symbolic context}

At the beginning of the 19th century, the above-described change in the balance of power is both initiated and accompanied by a generous funding of philological and historical subjects. Especially the core subjects of German human sciences - philosophy, classical philology, history and oriental studies - are experiencing a remarkable expansion. It is not until the 1950s that chairs for new subjects like Slavic studies, musicology and Egyptology are established on a larger scale. Despite the institutional expansion (cf. table 1), the teaching body is already reduced again at most universities at this point. ${ }^{7}$ Chairs are vacant for longer periods of time as soon as professors retire (cf. Baumgarten, 1997: 49-62). On the one hand, the reasons for this more cautious personnel policy are of an intellectual nature: the demise of Romanticism and German Idealism from the 1830s onwards is withdrawing the ideological foundation from the previously founded chairs. In addition to that, professors are suspected of being related to the revolutionary ideas of the pre-March era (Vormärz) just before the failed 1848 revolution. On

\footnotetext{
${ }^{5}$ All translations are made by the author.

${ }^{6}$ From the perspective of an established theologian and philosopher, the new balance of power at the university presents itself as follows: And indeed every teacher of jurisprudence or theology deserves to be laughed at and excluded from the university, if he does not feel the powers and the will in himself to achieve something of his own with distinguished success in the field of pure philosophy or ethics or philosophical history or philology. (Schleiermacher, 1956: 261-2)

${ }^{7}$ This is why the increase in the number of professors and lecturers at German faculties of philosophy in the 19 years from 1834 to 1853 is moderate (by 17.4 per cent from 224 to 263 ), while it is considerably higher in the following 20 years from 1853 to 1873 (by 52.1 per cent from 263 to 400) (cf. Lundgreen, 2009: 19-20).
} 
the other hand, staff cuts are justified by the decline in the number of students taking place in the middle of the 19th century. However, it is remarkable that German human sciences are generally threatened far less by this development than other disciplinary groups. Hence, the share of students in the human sciences in the total number of students is growing noticeably (cf. table 2). This decoupling of the general development can be seen as an indicator for a relatively independent mode of reproduction. And indeed, while German academics in general are composed of the elitist educated middle classes (Bildungsbürgertum), the fact that university families, in which professorships and lectureships are passed on from generation to generation, are a common phenomenon especially in German human sciences, confirms the particular dissociation of the disciplinary group (cf. Baumgarten, 1997: 93, 130).

As we have seen for population as well as for institutional differentiation, the material structure testifies the influence of German Idealism and neo-Humanism, representing the established and legitimate view that Bourdieu (1995: 159-71) calls orthodoxy - a dominant and dominating way of thinking. The same can be said for the symbolic structure of the field. At the beginning of the 19th century, the dominant notion of science strictly refuses applicability and specialization for an idea of legitimate research in the human sciences. Quite the contrary, research in the human sciences, understood as a contemplative occupation with classical texts, has to be protected from any kind of constraints or rules that could limit or restrict its freedom (cf. Grimm, 1984: 215-16; Humboldt, 2008: 920; Schleiermacher, 1956: 244-5, 262). Ideally, the result of this independent and introverted way of conducting research is pure insight and knowledge. Although it may seem so at first sight, this concept is not a contradiction to the close alliance between German scholars and the absolutistic Prussian state. From the university founders' viewpoint, it is above all the occupation with pure research in the human sciences that teaches students the independent thinking that enables them to become worthy citizens and capable members of the community. ${ }^{8}$

The indicators suggest that the struggles for a notion of Bildung take place in a context with a remarkable degree of closure on the material as well as the symbolic dimension. Regarding the institutional differentiation, we have seen that the vigorous expansion of chairs in the human sciences occurs on the basis of the orthodoxy of German Idealism and is, therefore, largely limited to core subjects. Likewise, the population of the field recruits itself in a closed mode of reproduction. The discursively constructed notion of science as pure and purposelessness research, founded on the basis of German Idealism as well, is engrained deeply into the practice of the whole field. This is the context in which the discourse of Bildung in German human sciences emerges and develops.

\section{Notion of Bildung}

In view of the context described above, it is not surprising that the concept of Bildung produced and received therein clearly shows the influence of neo-Humanism and of the philosophy of German Idealism. The discourse features three main focuses that are especially striking. First, Bildung in the human sciences is not focused on single abilities or competences, but it is rather meant to seize the personality as a holistic unit. A detailed and accurate description of the 'inner improvement and ennoblement' (Humboldt, 1960: 235) of humankind is made very difficult by

\footnotetext{
${ }^{8}$ The social legitimation of purposeless research in the human sciences can therefore be found in the teleological connection that is built with the interests of the state. Humboldt (1956: 384) is making this position clear when he says: 'The University namely has always close connections with practical life and the needs of the state, because it always undergoes practical affairs for him, the guidance of the youth.'
} 
the mystical and religious terminology often used by exponents of the ideal. ${ }^{9}$ Notwithstanding, what seems to be beyond dispute is that Bildung in the human sciences is seen as an interplay between the character of the researcher and the subject matter of research. The philosopher, theologian and classic philologist Friedrich Schleiermacher (1956: 301) remarked in 1808 that the whole character should participate in the act of humane insight and knowledge, so that 'the cultivation of the character [can] progress evenly with the one of the scientific mind'. The mind of the researcher is supposed to converge with the ideals found in the interaction with classical texts. This notion is led by the assumption that the classics have an effect on scholars and their students through the moral and aesthetic examples they embody. Thus, if the humanistic occupation is supposed to fulfil its cultivating potential, it is important for the researcher that 'from everything he carries out outside of himself, the illuminating light and the pleasant warmth shine back into his inner self. But for this purpose he has to bring home the mass of objects to himself, imprint into them the character of his mind and make both similar to each other', as Humboldt (1960: 237) emphasized in 1810.

The character that is ennobled through the synthesis with the subject matter of research is a scientific character. ${ }^{10}$ This definition of Bildung as decidedly scientific is the second main focus evolving in the discursive context of the first stage. It is expected that, by and during participation in the research process, key qualifications for a scientific occupation are imparted to the students. This makes research and scientific insight the most important outcome of the process of Bildung, while the actual results of research almost fade into the background (cf. McClelland, 1983: 316). Schleiermacher (1956: 276) concludes 'that learning in and of itself, whichever shape it may take, is not the purpose of the university, but knowledge; that it is not about filling up the memory, and not about enriching the intellect, but about stimulating a whole new life, a higher, truly scientific mind'. It is this very emphasis of the notion of Bildung that allows the Einheit von Forschung und Lehre to emerge. In 1849, the philologist and literary scholar Jacob Grimm (1984: 215-16) asks for 'the foundation, in which every single and the sciences altogether root, what fathers, nurtures and sates them? Abiding reference will have to be made to an inner and outer cause, who are almost inseparably intertwined and can barely be imagined without one another. I am talking about the urge for learning and teaching.'

Closely connected to the decidedly scientific character of Bildung is the third main focus, based on the idea of academic freedom and defining Bildung as utterly purposeless. The internal effect of Bildung as ennoblement of the character finds its equivalent in an intrinsic motivation of those who participate in the process of it. Grimm (1984: 235) is by no means an exception when he demands 'that everybody studied from an inner urge'.

According to the legitimate notion in the discourse, Bildung in the human sciences requires no additional legitimation or justification. It is exactly the lack of a direct purpose that is supposed to make Bildung so valuable for scholars, for students and, not least of all, for society. ${ }^{11}$ The aim is to learn the general rules of thought, not certain contents of positive knowledge. The necessary freedom for scholars and students to study and learn without being distracted by

\footnotetext{
${ }^{9}$ However, Ringer (1990: 87) sketches the universalistic focus of Bildung well when he writes: 'The materials which are 'experienced' in the course of learning are 'objective cultural values'.... He [the scholar, JH] does not only come to know them. Rather, the moral and aesthetic examples contained in the classical sources affect him deeply and totally. The whole personality is involved in the act of cognition.'

${ }^{10}$ As has been pointed out, the scientific character that the notion of Bildung in German human sciences is aiming for has nothing to do with science in the English sense of the word and is actually very much located on the ground of human sciences (cf. footnote 4).

${ }^{11}$ Thus, the connection of disinterestedness in human sciences with the interests of the state follows the logic that has already been described for the notion of science (cf. footnote 8). It is precisely the undirected and general Bildung that allows students to think independently and that enables them to become valuable citizens.
} 
external constraints is what Schleiermacher (1956: 277) has in mind when he underlines that the process of Bildung in the human sciences 'cannot at all be handled in a mechanistic way, but has to contain a character rather to the contrary, namely the one of freedom, within all parts of itself'.

In sum, the legitimate interpretation of Bildung as it is established in the discourse in German human sciences is founded on three main focuses - the ennoblement of the whole character, the decidedly scientific nature of Bildung, and its purposelessness. Those emphases can be understood as part of an orthodoxy made up of German Idealism and neo-Humanism, structuring the material and symbolic order of the entire field. Hence, the relative closure of the context of production and reception is reflected by the relative closure of symbolic struggles, whose result is the notion of Bildung that has just been described.

\section{Second stage, 1860-1960}

\section{Material and symbolic context}

The relative closure of the field of German human sciences during the first stage is followed by a partial opening in the second stage. With regard to the material structure, this can be demonstrated for both indicators. The structure of the population of the field is becoming more open because the number of students experiences a considerable increase. First signs of the expansion that is going to revolutionize most educational systems in the western world later on can be recognized as early as at the turn of the century (cf. table 2; Eulenburg, 1904: 187, 269; Jarausch, 1981: 16-23). This development can be observed for all disciplinary groups, and the increase in the human sciences is roughly proportional to the overall increase. Furthermore, the social background of the students in the human sciences changes as well. Especially descendants of lower and middle civil servants (mittleres and unteres Beamtentum) and of employees benefit from a more open mode of reproduction. As a result, the Bildungsbu "rgertum is losing a lot of influence (cf. tables 2 and 3). During the 1860s and 1870s, a transformation in the mode of recruitment of professors takes place due to a change in appointment policies that gives ministries more influence. This restricts the power of university families and familial structures in general. ${ }^{12}$ Another factor that should not be underestimated when it comes to a more heterogeneous population is that it is not until the beginning of the 20th century that women are allowed to register at universities (cf. Baumgarten, 1997: 157-8; McClelland, 1980: 183).

The expansion is accompanied by an institutional differentiation (cf. table 1). The main reasons for this differentiation are three demands with which society confronts the university. First, the institution is seen as an important part of the educational system and is, accordingly, held responsible for the employability of its graduates. An increasing number of students have to find their place on the labour market, and the universities are made accountable for this. Second, society confronts sciences at the university (i.e. sciences in the English sense, but also human sciences) with a need for continuous progress. Both demands lead to an institutional differentiation, and this is especially the case for the human sciences. ${ }^{13}$ At the same time, a

\footnotetext{
${ }^{12}$ Especially in light of a Bourdieusian argumentation we have to bear in mind that the more meritocratic selection is still taking place on the foundations of an 'inherited' habitus and specific forms of capital. Hence, an actual opening of the mode of reproduction is out of question, but at least sons of professors are now forced to pursue their academic careers at other universities than the ones their fathers are teaching at (cf. Baumgarten, 1997: 102). ${ }^{13}$ Baumgarten (1997: 159) notes that the institutional expansion in the German human sciences is taking place more rapidly than in the natural sciences. While the development in the natural sciences was 'rather left to chance
} 
general need for innovation in contents and in methods, partly attributable to the rise of the natural sciences, is putting the idealistic canon of the human sciences under pressure. Third, from the end of the 19th century onwards, sciences (including the human sciences) are becoming part of a nationalistic agenda whose purpose it is to prove the superiority of the German cultural nation (Kulturnation). German human sciences do not fail to live up to their responsibilities and play an important role in producing and inculcating a national selfknowledge (cf. Bialas and Rabinbach, 2007; Lepenies, 2006: 16-26). ${ }^{14}$

But it is not only the material structure that is shaped by the emerging competition with the natural sciences as well as by the modernization and industrialization of society in general. Similar developments can be observed for the symbolic structure. In terms of a notion of science in German human sciences, Wilhelm Dilthey's (1958a, 1959) systematic foundation of the disciplinary group can be viewed as the most influential conception in this stage. ${ }^{15}$ Obviously, the success of the systematization is based on its providing a synthesis of the two positions that divided the field of German human sciences at that time. Those who are responding to the objection that critical philosophy is ahistorical do so in the name of neo-Kantianism (cf. Beiser, 2008). Windelband $(1894,1921)$ and his pupil Rickert $(1902,1926)$ are among the defenders of Kantian philosophy and of the need to take a higher universal standpoint, their aim being to keep philosophy a science without falling for the relativism of Historicism (Historismus), a decidedly empirical approach that is interested in an objective explanation of individual events (cf. Iggers, 1995). Dilthey takes up both approaches, providing Historicism with the foundation of the philosophy of enlightenment it lacks, but at the same time refusing the neo-Kantian stance he perceives as dogmatic. He positions himself 'in contrast to the dominating empiricism as well as to speculation' (Dilthey, 1959: 124), conciliating the positivistic tendency of Historicism with introspective philosophy. According to Bourdieu, the notion of science becoming apparent in Dilthey's methodological legitimization of the human sciences can be interpreted as a translation of the generally emerging modern notion of science into the specific logic of the field of human sciences. While the hermeneutic method Dilthey establishes is still clearly influenced by Kantian philosophy, it is the endeavour to make objective statements on the basis of systematized methods at all that is a sure indication of the newly emerging empirical-positivistic notion of science. The broad debates taking place in human sciences at the turn of the century are not limited to Historicism and neo-Kantianism; they also spill over to the emerging social sciences (cf. Simmel, 1923; Weber, 1922, whose methodological approach is heavily influenced by Rickert). The general search for a methodology in its own right, serving as a distinction and as a legitimation in the new scientific climate, is a positive sign of the dominance natural sciences are gaining (cf. Hamann, 2009: 94-101; Huschke-Rhein, 1979: 98-105).

\footnotetext{
... because of a lack of traditions', the expansion in the human sciences took place along the lines of the humanistic concept of Bildung and could therefore 'take up older structures from the eighteenth century and push on the process of scientification by determined appointments of prominent scholars'. Around 1880, a reorganization of the faculty structure gave birth to faculties of human sciences, faculties of natural sciences, and also faculties of social sciences. In addition to that, studies from Lundgreen (1983: 157-60) and Ferber (1956: 62-6) give evidence of the specialization in German human sciences by pointing out the increasing number of subjects in the disciplinary group and a higher growth rate than in the natural sciences.

${ }^{14}$ Muhlack's example (1990: 98-9) for history illustrates that the engagement for a national culture is actually a specific form of applicable science: 'Due to the controversial involvement of authors of historicism in the German national movement ... the practical relevance of historical science and education comes to the fore more and more, until it becomes noticeable in the very concepts of philosophy of science.'

${ }^{15}$ Schnädelbach (1983: 154) does not estimate Dilthey's influence too generously when he states that his 'outlines of methodology of the humanities ... had such a strong effect on the respective discussion from the turn of the century onwards, that everything up to now can, with only slight exaggeration, be labelled as a series of footnotes to Dilthey'.
} 
Another result of the opening of symbolic struggles in the human sciences is that philosophy has lost its status of a leading discipline. In the political climate of the German Reich from 1871 to 1945 , history and linguistics are far more responsive to utilization in regards of a German National narrative. Consequently, those are the disciplines that gain influence and social power (as opposed to academic power, cf. Bourdieu, 1988: 73-4) in the field of human sciences. In addition to that, Habermas (1992: 3-9) suggests that it is not only external influences contributing to the marginalization of philosophy, but that the internal break with the tradition of the discipline is adding to the development as well.

The distinct growth in the number of students, their changed social composition and the transformed mode of recruiting of professors all point towards a partial opening of the material structure. An analogous development has been demonstrated for the symbolic structure of the field, where the orthodoxy made up of German Idealism and neo-Humanism is drawing to an end. However, it is noteworthy that there is no complete opening of the symbolic structure. Dilthey's synthesis contributes greatly to this inertia, integrating and hedging in the symbolic struggles that break out after the end of the dominance of the orthodoxy.

\section{Notion of Bildung}

The end of the relatively closed unity of German human sciences is also reflected by the discourse of Bildung that is taking place. The three main focuses of the ideal in the first stage cannot maintain their legitimacy unconditionally. First, the holistic emphasis, interpreting Bildung as an ennoblement of the whole character, has lost its value in the discursive struggles. The second emphasis, stressing the purposelessness and autonomy of Bildung, is not legitimate without substantial restrictions either. Nonetheless, it is possible to maintain the validity of this representation due to a reinterpretation. The German human sciences are able to meet society's demand for applicability by satisfying the need for teachers, which has grown significantly during the general opening of the educational system. As a result, the increased number of students in the human sciences can be compensated for within the traditional educational mission of the disciplinary group for the time being. The decidedly scientific nature of Bildung as the third emphasis remains dominant in the second stage. The concept is still defined in a scientific way and is still assumed to be obtained in the process of a scientific occupation. However, what has become controversial is what the cultivating capacity of science is actually made up of. In other words, the participants in symbolic struggles can agree on the formula Bildung durch Wissenschaft, but what they cannot agree upon is the kind of Bildung and the kind of Wissenschaft it describes. The struggles for interpretational hegemony in this question take place along two fronts.

First, the fact that a humanistic notion of Bildung is generally called into question constitutes a front on which the discursive context as a whole fights against the loss of legitimacy. Interestingly enough, at this point in time a discourse of Bildung is becoming prominent in the natural sciences as well. ${ }^{16}$ It can be seen as part of the more fundamental competition for

\footnotetext{
${ }^{16}$ Ben David (1971: 118) even puts the whole rise of empirical science down to the revolt against the philosophy of the newly founded universities. And indeed, there are numerous examples of this revolt. Emil Heinrich Du BoisReymond (quoted in Engelhardt, 1990: 112), physiologist and rector of the University of Berlin, effectively attacks the symbolic power of the human sciences, demanding 'cone sections instead of Greek scripts'. The chemist Justus Liebig (quoted ibid.) fears that philosophical cultivation may cause 'self-overestimation, vanity and pretentiousness' in the academic youth, while the 'overgrowing Humanism [opposes] the progress of natural sciences and medicine'. Another example is the chemist Albert Ladenburg (1912: 146), anticipating Charles P. Snow's 1959 Rede Lecture (see Snow, The Two Cultures [2008]) when he criticizes that a lack of culture is only diagnosed for those 'making grammatical mistakes or not remembering important dates. But one who does not
} 
scientific dominance between the natural and the human sciences in the late 19th century (cf. Veit-Brause, 2001). The philosopher Karl Jaspers (1946: 35) depicts the interpretational efforts taking place against this backdrop. According to him, both disciplinary groups, human and natural sciences, have 'the tendency to give themselves priority and declare themselves the actual, real science. ... The spiritualization is confronted with the natural sciences and their knowledge of reality, in which our whole mental knowledge is intertwined as well.'

Second, the discourse of Bildung in the human sciences is divided internally by the front between neo-Kantianism and Historicism. Exponents of the latter champion a notion of Bildung that is supposed to provide clear directions for everyday life and to qualify immediately for social practice. Following this ideal, the historian Johann Gustav Droysen (1977: 449, cf. 269) praises the applicability of historical Bildung in the lectures he holds from 1857 onwards: 'Historical studies are the foundation for political education and culture. The statesman is the practical historian.' When Dilthey is integrating Historicism and neo-Kantianism in his foundation of the human sciences, his first and foremost goal is not to create a concept of Bildung. However, the hermeneutic method he systematizes has a cultivating capacity 'which strives to establish the perfection of the events and their connections in the spiritual life' (Dilthey, 1963: 26). In the process of understanding, Dilthey's hermeneutics of the human sciences (geisteswissenschaftliche Hermeneutik) is supposed to bring about a transformation of the self - this is where Humboldt's idea of interplay between the character of the researcher and the subject matters of research re-emerges. ${ }^{17}$

Dilthey's epistemological foundation of the disciplinary group provides a point of reference that is able to integrate the different positions in the discourse in the field of human sciences. Notwithstanding, we can observe a relatively heterogeneous knowledge structure in comparison to the first stage. Exponents of Historicism only represent the most successful approach that is able to establish itself and enforce an orthodoxy challenging Schelling's and Hegel's absolute Idealism as well as early neo-Kantian Idealism which itself consists of several differing schools; cf. Adair-Toteff, 2003). Besides that, it is remarkable to see that Bildung as a subject matter of symbolic struggles in the human sciences is altogether underrepresented in this period. The focus of the struggles is rather on developing a methodology for the German human sciences, laying down methods as well as subject matters and questions of research that are actually able to compete with those of the rapidly growing natural sciences (cf. Hamann, 2009: 73-9). Against this background, an investment in the interpretational struggles for a certain representation of Bildung seems to be less rewarding.

\section{Third stage, 1960-99}

\section{Material and symbolic context}

While a closure of the material and the symbolic structure could be sustained at least partially during the second stage, the beginning of the third stage is characterized by an extensive social opening of the university as a whole. The demographical, economical and political reasons for

know what the change of seasons is based on, or does not know the physiological significance of respiration, is not necessarily considered illiterate because of that.'

${ }^{17}$ Elsewhere, Dilthey (1958b: 126) describes this process as a unique feature that raises the hermeneutics of the human sciences above a method of the natural sciences: 'If the mind wanted to contrast its own creations merely as something objective and empirical and analyse them by the outer method of the natural sciences, a selfalienation of mind towards its own creations occurred.' 
the educational expansion are well documented (for a sample of the works dealing with this transformation, cf. Oehler, 1998 and Windolf, 1997).

The dramatic increase in student numbers displays about the same extent in German human sciences as it does in other disciplinary groups. In this regard, the human sciences do not account for a special case (cf. table 2). But it is not only the quantity of students that changes. The third stage sees a likewise dramatic change in their social background as well. Hartmann (2002: 51) argues that 'the students of 1959 . . show a remarkably more exclusive social recruitment ... than those of the following years'. While the quantity of the general personnel in German human sciences reflects this development, the number of professors increases to a much lesser extent, especially in relation to the number of the students (cf. Lundgreen, 2009: $49,200)$. However, there is not only a change in quantity of general personnel and, considerably less so, professors, but also a significant opening regarding their mode of recruitment. Careers at the university even seem to be dominated by post-doctoral students from the working class and the broader middle class (Hartmann, 2002: 114). Of course, the crucial bottleneck arrives right after the doctorate, which is especially true for German universities and their hierarchic institutional chair structure. Yet, it still seems fair to assume that the influence the social background has on the mode of reproduction has declined compared with the long established social structure of the university as a corporation of professors and with a traditional chair system (Ordinarienuniversität).

In comparison with sciences as a whole, the degree of institutional differentiation in the German human sciences is lower. One main reason for this is that, up until the 1980s, no proper science policy exists for them. ${ }^{18}$ Tellingly, it is educational policy discovering the human sciences as its domain, and it can be attributed to this policy area - and not to science policy - that the number of professors still grows sevenfold (Weingart et al., 1991: 274; cf. table 4). Bearing in mind that development, it is not surprising that there are two groups of disciplines showing an especially high growth rate. On the one hand, there is institutional differentiation in smaller subjects like Far Eastern linguistic and cultural studies or medieval Latin, which have a low base level and, therefore, a high growth potential. On the other hand, there is differentiation in the established subjects that play a central role for the education of teachers, i.e. history, German studies, English studies and American studies as well as Romance studies and philosophy.

The extensive social opening of the field of German human sciences can also be detected on the symbolic dimension. The notion of science in the human sciences of the second half of the 20th century experiences an opening that sees new methods of research on the rise. A new understanding of relevance for texts develops, right through to an extended notion of 'text' in general. Subject matters of the human sciences, formerly either classical or national literature, are to be contextualized, because the societal environment in which these texts have been produced becomes more important and gains legitimacy as a subject matter in its own right. This can be interpreted as a turn towards the flourishing social sciences or as a more general cultural turn across social and human sciences (cf. Hall, 1990, McLennan, 1998, for similar developments in the British context). This development is taking place in history, where the historical social science (Historische Sozialwissenschaft) forms an influential school (cf. Kocka, 1990; Wehler, 1973). The same can be observed for literary studies, where the rise of reception theory adds weight to the historical and social conditions in which cultural products are produced and received (cf. Schücking, 1961; Voßkamp, 1990). Another example is German

\footnotetext{
${ }^{18}$ It took the council founded in 1957 as an advisory body to the German federal government and the state governments (Wissenschaftsrat) almost 30 years to discover the human sciences as a disciplinary group in its own right (cf. Weingart et al., 1991: 38-53).
} 
studies, where trivial literature and non-fiction are discovered as subject matters in addition to the established canon (cf. Grimminger, 2000; Röther, 1980). ${ }^{19}$

The changed notion of science also becomes apparent in the various attempts to legitimize the human sciences towards society. The most influential attempt in this regard has to be Odo Marquard's (1986) thesis of compensation. The philosopher champions the - controversially discussed - assumption that the human sciences' purpose is to compensate for the social damages that have been caused by modernization. In other words, Marquard claims that the disciplinary group is necessary to balance the losses in the Lebenswelt that are caused by those technological innovations that, in the end, have been pushed forward by natural sciences and engineering. Taking into account the difference in legitimacy and prestige ascribed to German human sciences at the beginning of the 19th century, when the faculty of philosophy has been declared the first at the university (cf. Fichte, 1910: 26; Schleiermacher, 1956: 239-41, 250, 260; Steffens, 1910: 261), a merely compensational function is a rather humble and sober foundation on which to base the status of the disciplinary group.

Considering the developments of the material and symbolic context in stage three, it is obvious that a profound change has taken place. The extensive social opening on the material dimension of the field increases the tension on the symbolic dimension to a degree where Dilthey's integration is not sufficient any more. The result is a structure of the field that is largely open both on the material dimension of allocation and on the symbolic dimension of interpretation and attribution. As we will see in the following paragraphs, the complete transformation of the framework for the production and reception is reflected in a fundamentally changed discursive construction of Bildung.

\section{Notion of Bildung}

The postwar period is characterized by an intellectual reconstruction that is taking place in the human sciences as well as elsewhere in German society. In the first years, this means a return to traditional values and ideas. However, after a short renaissance, the notion of Bildung that is based on Idealism and neo-Humanism is rapidly losing its backing from the mid-1960s onwards. Society's demand for a form of Bildung that is in fact vocational education cannot be satisfied merely by the education of teachers any more. Students in the human sciences, who by and by realize the changed mode of reproduction in the field, lay claim to the applicability of their competences beyond the realms of the university (cf. Bourdieu, 1988) ${ }^{20}$ It is not surprising that this development is reflected by the discourse of Bildung in the field. As at the university in general, the new main focus of Bildung in the discourse in the human sciences is the orientation towards the labour market. In the course of time two interpretations of this emphasis can be identified.

Given the material structure of the field, the purposelessness of Bildung has in large parts lost its legitimacy. The philosopher Joachim Ritter (1974: 109) comments on this when he states that '... a 'free' Bildung through participation in pure science cannot be preserved in the long

\footnotetext{
${ }^{19}$ The opening of the symbolic structure in German studies is also displayed by the change of topics of the annual meeting of the official association of German scholars in German studies (Tagungen des Deutschen Germanisten-Verbandes) in the years from 1953 to 2007 (compilation in Hamann, 2009: 216-19).

${ }^{20}$ This realization becomes manifest only gradually because 'there is a continuously growing gap between the level of aspiration and the level of achievement, between the ideal representation and the reality of scientific and pedagogical practices' (Bourdieu, 1988: 112). As a result of this discrepancy, the discrepancy between expectations towards and demands of studying makes for irrational scheduling of and alienation from subjects that are related to science (including human sciences) and are not directly connected to applicability on the labour market (cf. Oehler, 1998: 428).
} 
run when it has been taken out of the societal context; as a 'lift up over practical life and its demands for purpose', it contradicts the elementary necessities of current reality.' In the light of the new challenges that teaching is facing, the coupling of scientific Bildung and research cannot be preserved either. All in all, the third stage is characterized by a restructuring of the university system towards a higher education sector. This is the backdrop against which Georg Picht's (1964) analysis of Die deutsche Bildungskatastrophe [The German Catastrophe of Bildung] and Ralf Dahrendorf's (1965) claim that Bildung ist Bürgerrecht [Bildung is a Civil Right] receive broad attention beyond the discourse in the human sciences. The concept subsequently emerging in the discourse is a participative interpretation aiming at inclusion rather than an elitist social closure based on the Bildungsbürgertum. The social opening of the field has now reached dimensions in which the education of teachers that has spared the human sciences broader changes up to this point does not suffice to provide employment for the majority of graduating students. Bearing this in mind, Hermann Müller-Solger and Ludwig Gieseke (1977: 5) demand in the journal of the official association of German scholars in German studies (Mitteilungen des Deutschen Germanisten-Verbandes) that the "new generation of university teachers [have to] seek and also get safeguarding by employment possibilities outside of the university to an increasing degree'. ${ }^{21}$ What can be witnessed in the first 20 years of the third stage is that the discourse of Bildung is focused on participation, because this is seen as the prerequisite for inclusion into the labour market.

However, broad inclusion is achieved in the 1970s, and from the 1980s onwards a new interpretation of orientation towards the labour market gains ground. Bildung is now defined in a more competitive way, namely as an allocation of human capital, reintroducing an elitist understanding that has been banned during the participative interpretation. The dominant notion now represents a preparation for social practice, and in the end this is achieved by the disciplines' programmatic 'openness for the labour market' (BDA and HRK, 2003: 21), as unambiguously pointed out in a joint publication of the Confederation of German Employers' Associations (Bundesvereinigung der Deutschen Arbeitgeberverbände) and the German Rectors' Conference (Hochschulrektorenkonferenz). The main emphasis has now moved from broad participation in higher education to increased competitiveness by means of higher education. The literary scholar Wolfgang Frühwald (1991: 110) seems to confirm this when he agrees with Hubert Markl, then president of the German Research Foundation (Deutsche Forschungsgemeinschaft), who '... names the development of skills that are "needed urgently in all areas of life' as personality-building consequences of independent research: hard work, deep satisfaction through performance, self-criticism, fair and dedicated cooperation, modesty, the ability to differ between important and unimportant things ... but these are at least educating consequences in the human sciences as well.'

The media are established as a legitimate field of employment by now. After all, museums, the press and publishing houses are already described as 'classical' branches for graduates of the human sciences on the 1991 Tagung des Deutschen Germanisten-Verbandes (Stooß, 1991: 172). ${ }^{22}$ More recent studies verify that the alternative employment possibilities Müller-Solger

\footnotetext{
${ }^{21}$ In the same publication, Karl Maly (1977: 9) bemoans: 'Just five years ago you would hardly have asked yourself seriously the question which employment possibilities arise for the scholars of German studies. Even if one did not know their accurate numbers, one was aware of the fact that, in the end, the school would accommodate all those who would not seek and find their place at the universities or in the reservations of literature.'

${ }^{22}$ About 10 years later in a talk 'On the Future of the Human sciences', the philosopher Julian Nida-Rümelin (2003: 10) highlights the symbolic opening of the disciplinary group when he praises the almost universal applicability of the contents that are imparted: 'But what is happening at present is something different, namely that it matters to have studied at all, and apparently the expectation on the labour market is that something has been learned in these years at the university - also and especially in the human sciences. And apparently this is sufficient to offer a majority of 94-95 per cent a real professional perspective - which, admittedly, has in content
} 
and Gieseke have been talking about in the 1970s can still be found mainly in the media (cf. Briedis et al., 2008: 43-7).

In sum, the changed notion of Bildung in the third stage reflects the dramatic transformation of the context the discourse is taking place in. The field of German human sciences is opened on the material as well as the symbolic dimension by now. The symbolic struggles give rise to a concept of Bildung whose main focus is the orientation towards the requirements of the labour market. This emphasis is first interpreted in a rather participative way, while an interpretation based on competitiveness gains ground later on. The traditional legitimacy of a classical canon gives way to flexibility in content, reflecting the flexibility that is expected from the graduates on the labour market.

\section{Concluding remarks}

The development in the self-reflective discourse in the field of German human sciences represents a remarkable transformation of the dominant concept of Bildung. In the first stage, the discursive attributions are relatively homogeneous, structured by an orthodoxy made up of German Idealism and neo-Humanism. The notion results from symbolic struggles that take place in a context that is structured by this orthodoxy as well. The indicators suggest that the material structure is closed, and the same can be said for the symbolic structure. In the second stage, the indicators refer to a change in the twofold structure. The change is especially obvious on the material dimension, putting the symbolic dimension under pressure. Accordingly, the traditional conception of Bildung is put under pressure as well, and its legitimacy is confined. In the third stage, the pressure increases considerably. The educational expansion increases exponentially the openness of the material dimension of the field. As the fundamentally changed notion of science suggests, an opening of the symbolic structure is taking place eventually. These developments increase the tension between the context of production and reproduction on the one hand, and the traditional ideal on the other hand, to a degree where it has to be resolved. In the end, the discursive construction and interpretational efforts within this context generate an idea of Bildung that is a reflection of these circumstances - the prevalent notion of Bildung in the respective discourse currently taking place in German human sciences is now closer to an idea of practical learning and vocational training. The previous notion of Bildung as developed in the first stage has been transformed thoroughly and lost most of its legitimacy and authority in the process. This situation is reminiscent of the discussion taking place in England for quite a while now (cf. Baker, 2011; Coiffait, 2011; Collini, 1999; Head, 2011; Observer, 2010; Salter and Tapper, 2002; Schwartz, 2011). It is noteworthy that the discourses about Bildung in German and English human sciences seem to head in the same direction, while their starting points differed considerably.

Coming back to the questions raised at the beginning of this article, the empirical example that has been put forward highlights at least three points about the relationship between knowledge structures and the context they are produced and received in. First, the context-sensitivity of ideas - or their textual representation - has been emphasized and demonstrated. The field of the human sciences has been put forward as one possible conceptualization of a space that structures scientific speech (cf. Livingstone, 2007). The construction and reception of ideas is taking place during symbolic struggles for interpretative hegemony. Those struggles are contextual as well, their outcome depends both on the disposability of different material

often little to do with the studies. But what does that mean: Little to do? Is it not possible that it plays a part whether one is able to adjust to other cultures, and can therefore be transferred to other countries without the economical activities of the relevant enterprise failing?' 
resources and on the availability of other symbolic knowledge structures. Following up on this, the example suggests, second, that it is exactly the combination of material and symbolic context factors that can provide new insights into questions about the contextuality of knowledge. Bourdieu's field theory has proved to be useful for approaching this twodimensional structure of allocations and ascriptions. The indicators employed in this article can only be a first step to approximating this context systematically. Third, the article underlines how valuable historical analyses can be for the kind of questions asked here. While research into the circulation of concepts and ideas across borders of fields and countries is certainly an important approach, a historical perspective allows new insights in comparison.

\section{Tables}

Table 1: Number of independent organisational entities at German universities (ioe), average number of organisational entities at German universities (aoe), average number of organisational entities in subjects of mathematics or natural sciences (mnsoe) and of organisational entities in linguistic and cultural studies (lcsoe) as well as number of independent organisational entities in faculties of linguistic and cultural studies at selected universities (oeB = Berlin, oeM = Munich, oeL = Leipzig, oeH = Heidelberg, oeG = Göttingen)

\begin{tabular}{|c|c|c|c|c|c|c|c|c|c|}
\hline & ioe & aoe & mnsoe & lcsoe & oeB & oeM & oeL & oeH & oeG \\
\hline 1830 & 231 & 17 & 5.20 & 2.20 & 1 & - & - & 1 & 1 \\
\hline 1840 & 312 & 18 & 5.70 & 2.80 & 1 & - & 3 & 1 & 1 \\
\hline 1850 & 398 & 20 & 6.90 & 3.20 & 1 & 4 & 2 & 1 & 4 \\
\hline 1860 & 446 & 22 & 7.20 & 3.40 & 2 & 5 & 3 & 2 & 6 \\
\hline 1870 & 552 & 26 & 8.80 & 4.00 & 2 & 6 & 4 & 2 & 6 \\
\hline 1880 & 708 & 34 & 10.10 & 6.10 & 3 & 7 & 10 & 4 & 6 \\
\hline 1890 & 840 & 40 & 10.80 & 8.10 & 9 & 7 & 14 & 4 & 11 \\
\hline 1900 & 988 & 47 & 11.80 & 10.00 & 11 & 14 & 23 & 8 & 10 \\
\hline 1910 & 1127 & 54 & 12.40 & 12.30 & 16 & 18 & 27 & 10 & 10 \\
\hline 1920 & 1419 & 59 & 11.80 & 14.90 & 20 & 23 & 37 & 12 & 10 \\
\hline 1930 & 1743 & 76 & 15.00 & 18.70 & 27 & 28 & 42 & 16 & 16 \\
\hline 1940 & 2020 & 88 & 15.40 & 22.00 & 35 & 29 & 43 & 20 & 20 \\
\hline
\end{tabular}


These are proofs of the final publication available at SAGE via History of the Human Sciences: https://doi.org/10.1177/0952695111421865

Table 2: Number of students in German human sciences in relation to the overall number of students

\begin{tabular}{|c|c|c|c|}
\hline & Students in human sciences & Students overall & Percentage \\
\hline 1830 & 2,937 & 15,870 & 18.5 \\
\hline 1840 & 3,064 & 11,567 & 26.5 \\
\hline 1850 & 3,102 & 12,426 & 25.0 \\
\hline 1860 & 3,976 & 12,444 & 32.0 \\
\hline 1870 & 2,703 & 12,256 & 22.0 \\
\hline 1880 & 4,609 & 21,432 & 21.5 \\
\hline 1890 & 2,948 & 28,359 & 10.4 \\
\hline 1900 & 4,855 & 33,688 & 14.4 \\
\hline 1910 & 12,543 & 53,351 & 23.5 \\
\hline 1920 & 12,620 & 86,416 & 14.6 \\
\hline 1930 & 21,911 & 95,807 & 22.9 \\
\hline 1954 & 16,055 & 106,138 & 15.1 \\
\hline 1957 & 24,044 & 130,338 & 18.4 \\
\hline 1960 & 33,038 & 155,228 & 21.3 \\
\hline 1963 & 42,859 & 232,429 & 18.4 \\
\hline 1966 & 47,813 & 243,642 & 19.6 \\
\hline 1969 & $45,073^{*}$ & 304,720 & $14.8^{*}$ \\
\hline 1972 & $23,904 *$ & 456,853 & $5.2 *$ \\
\hline 1975 & 145,388 & 620,196 & 23.4 \\
\hline
\end{tabular}


These are proofs of the final publication available at SAGE via History of the Human Sciences: https://doi.org/10.1177/0952695111421865

\begin{tabular}{|c|c|c|c|}
\hline 1978 & 165,878 & 690,467 & 24.0 \\
\hline 1981 & 193,649 & 794,142 & 24.4 \\
\hline 1984 & 213,677 & 930,748 & 22.9 \\
\hline 1987 & 204,631 & $1,047,157$ & 19.5 \\
\hline 1990 & 259,552 & $1,148,686$ & 22.6 \\
\hline 1993 & 296,448 & $1,392,808$ & 21.3 \\
\hline 1996 & 314,678 & $1,409,345$ & 22.3 \\
\hline 1999 & 303,640 & $1,364,803$ & 22.2 \\
\hline 2002 & 341,886 & $1,382,261$ & 24.7 \\
\hline
\end{tabular}

* In 1969, teacher trainings for Volks-, Berufs-, Gewerbe- and Handelsschulen are not included. In 1972, no teacher training is included at all. (Titze, 1987; Weingart, et al., 1991: 109; Wissenschaftsrat, 2006: 124; 2008: 106)

Table 3: Percentage of male students at Prussian universities in the subjects old and new philologies and history, sorted by occupation of their fathers

\begin{tabular}{|c|c|c|c|c|c|c|}
\hline & $\begin{array}{c}\text { senior service } \\
\text { (Höhere } \\
\text { Beamte) }\end{array}$ & $\begin{array}{l}\text { middle and } \\
\text { lower service } \\
\text { (Mittlere und } \\
\text { untere Beamte) }\end{array}$ & $\begin{array}{l}\text { freelance } \\
\text { (Freie } \\
\text { Berufe) }\end{array}$ & $\begin{array}{l}\text { trade and } \\
\text { commerce } \\
\text { (Handel und } \\
\text { Gewerbe- } \\
\text { treibende) }\end{array}$ & $\begin{array}{l}\text { employees } \\
\text { (Angestellte) }\end{array}$ & $\begin{array}{l}\text { labourers } \\
\text { (Arbeiter) }\end{array}$ \\
\hline 1890 & 15.21 & 24.93 & 3.94 & 34.72 & 5.77 & $\overline{0.70}$ \\
\hline 1895 & 19.16 & 26.20 & 3.69 & 35.57 & 4.64 & 0.34 \\
\hline 1902 & 14.43 & 32.47 & 3.35 & 33.33 & 5.09 & 0.61 \\
\hline 1905 & 12.88 & 37.01 & 2.63 & 30.20 & 5.87 & 0.60 \\
\hline 1911 & 10.75 & 39.09 & 2.40 & 30.47 & 6.37 & 0.52 \\
\hline 1925 & 13.59 & 36.35 & 4.81 & 19.68 & 11.54 & 2.36 \\
\hline
\end{tabular}




\begin{tabular}{|l|r|r|r|r|r|r|}
\hline 1930 & 9.78 & 43.67 & 3.30 & 18.17 & 14.39 & 4.48 \\
\hline
\end{tabular}

Table 4: Distribution of chairs in the German human sciences at six selected* universities

\begin{tabular}{|l|r|r|r|r|r|r|r|}
\hline & Kiel & FU Berlin & Bochum & Duisburg & Passau & Stutgart & added \\
\hline 1954 & 19 & 29 & - & - & - & 3 & 51 \\
\hline 1969 & 36 & 55 & 38 & - & - & 11 & 140 \\
\hline 1972 & 43 & 153 & 64 & 5 & - & 14 & 279 \\
\hline 1975 & 36 & 156 & 75 & 18 & - & 18 & 303 \\
\hline 1984 & 58 & 211 & 108 & 29 & 18 & 23 & 447 \\
\hline
\end{tabular}
(Universität/Technische Universität/Gesamthochschule) as well as the organisational structure (faculty/department) (Weingart, et al., 1991: 252-266)

\section{References}

Adair-Toteff, C. (2003) 'Neo-Kantianism: the German Idealism Movement', in T. Baldwin (ed.) The Cambridge History of Philosophy 1870-1945, Vol. 1: The Cambridge History of Philosophy 1870-1945. Cambridge: Cambridge University Press, pp. 27-42.

Baker, S. (2011) 'Hefce Shows how the Axe will be Wielded', Times Higher Education.

Baumgarten, M. (1997) Professoren und Universitäten im 19. Jahrhundert: zur Sozialgeschichte deutscher Geistes- und Naturwissenschaftler [Professors and Universities in the Nineteenth Century: Social History of German Human and Natural Scientists]. Göttingen: Vandenhoeck \& Ruprecht.

BDA and HRK (2003) Wegweiser in die Wissensgesellschaft. Zur Zukunfts- und Wettbewerbsfähigkeit unserer Hochschulen [Guide to the Knowledge-Based Society. About the Sustainability and Competitiveness of our Universities]. Berlin.

Beiser, F. (2008) 'Historicism and neo-Kantianism Studies', History and Philosophy of Science 39: 554-64.

Ben-David, J. (1971) The Scientist's Role in Society. A Comparative Study. Englewood Cliffs, New Jersey: Prentice Hall.

Bialas, W. and Rabinbach, A. (2007) Nazi Germany and the Humanities. Oxford: Oneworld.

Bourdieu, P. (1988) Homo Academicus. Cambridge: Polity Press.

Bourdieu, P. (1991) Language and Symbolic Power. Cambridge: Polity Press. 
Bourdieu, P. (1995) Outline of a Theory of Practice. Cambridge: Cambridge University Press.

Briedis, K., et al. (2008) Berufsverbleib von Geisteswissenschaftlerinnen und Geisteswissenschaftlern [Professional Future of Human Scientists]. Hannover: HochschulInformations-System.

Coiffait, L. (2011) Blue Skies: New thinking about the Future of Higher Education. London: Pearson Centre for Policy and Learning.

Collini, S. (1999) 'Against Prodspeak: 'Research' in the Humanities', in S. Collini (ed.) English Pasts. Essays in History and Culture. Oxford: Oxford University Press, pp. 233-51.

Dahrendorf, R. (1965) Bildung ist Bürgerrecht. Plädoyer für eine aktive Bildungspolitik [Bildung is a Civil Right]. Hamburg: Nannen.

Diemer, A. (1974) 'Geisteswissenschaften', in J. Ritter (ed.) Historisches Wörterbuch der Philosophie. Bd. 3: G-H. Darmstadt: Wissenschaftliche Buchgesellschaft, pp. 212-5.

Dilthey, W. (1958a) 'Der Aufbau der geschichtlichen Welt in den Geisteswissenschaften' [The Composition of the Historical World in the Human Sciences], in B. Groethuysen (ed.) Wilhelm Dilthey. Gesammelte Schriften, VII. Band. Stuttgart: B.G. Teubner.

Dilthey, W. (1958b) 'Die geistige Welt. Einleitung in die Philosophie des Lebens. 2. Hälfte: Abhandlungen zur Poetik, Ethik und Pädagogik' [The Mental World. Introduction to the Philosophy of Life. 2nd half: Essays on Poetics, Ethics and Pedagogy], in G. Misch (ed.) Wilhelm Dilthey. Gesammelte Schriften, VI. Band. Stuttgart: B.G. Teubner.

Dilthey, W. (1959) 'Einleitung in die Geisteswissenschaften. Versuch einer Grundlegung für das Studium der Gesellschaft und der Geschichte' [Introduction to the Human Sciences. Essay on the Foundation of the Study of Society and History], in B. Groethuysen (ed.) Wilhelm Dilthey. Gesammelte Schriften, I. Band. Stuttgart: B.G. Teubner.

Dilthey, W. (1963) Über die Möglichkeit einer allgemeingültigen pädagogischen Wissenschaft [About the Possibility of a Universally Valid Pedagogical Science]. Weinheim: Beltz.

Droysen, J. G. (1977) Historik [History]. Stuttgart, Bad Cannstatt: Frommann - Holzboog.

Engelhardt, D. v. (1990) 'Der Bildungsbegriff in der Naturwissenschaft des 19. Jahrhunderts' [The Notion of Bildung in the Natural Sciences of the 19th Century], in R. Koselleck (ed.) Bildungsbürgertum im 19. Jahrhundert. Teil II: Bildungsgüter und Bildungswissen. Stuttgart: Klett-Cotta, pp. 106-16.

Eulenburg, F. (1904) Die Frequenz der deutschen Universitäten. Von ihrer Gründung bis zur Gegenwart [Frequency of German Universities. From their Foundation to the Present]. Leipzig: B. G. Teubner.

Frühwald, W. (1991) 'Humanistische und naturwissenschaftlich-technische Bildung: die Erfahrung des 19. Jahrhunderts' [Humanistic and Scientific-Technical Bildung: The Experience of the 19th Century], in W. Frühwald, et al. (eds) Geisteswissenschaften heute. Frankfurt/M.: Suhrkamp, pp. 73-111.

Geldsetzer, L. (1974) 'Die Geisteswissenschaften - Begriff und Entwicklung.' [The Geisteswissenschaften - Notion and Development], in H. Rombach (ed.) Wissenschaftstheorie. Bd. 1: Probleme und Positionen der Wissenschaftstheorie. Freiburg/Br.: Herder, pp. 141-50. 
Grimm, J. (1984) 'Über Schule Universität Academie' [About School University Academy], in W. Neumann and H. Schmidt (eds) Jacob Grimm. Reden in der Akademie. Berlin: AkademieVerlag, pp. 212-49.

Grimminger, R. (2000) 'Krisen, Innovationen und andere Erbschaften. Drei Jahrzehnte Germanistik' [Crises, Innovations and other Legacies. Three Decades of German Studies], in S. Vietta and D. Kemper (eds) Germanistik der siebziger Jahre. Zwischen Innovation und Ideologie. München: Wilhelm Fink Verlag, pp. 59-81.

Habermas, J. (1992) Postmetaphysical Thinking. Philosophical Essays. Massachusetts: MIT Press.

Hall, S. (1990) 'The Emergence of Cultural Studies and the Crisis of the Humanities', October 53: 11-23.

Hamann, J. (2009) Der Preis des Erfolges. Die 'Krise der Geisteswissenschaften' in feldtheoretischer Perspektive [The Price of Success. The 'Crisis of the Humanities' in Perspective of Field Theory]. Bamberg: University of Bamberg Press.

Hartmann, M. (2002) Der Mythos von den Leistungseliten: Spitzenkarrieren und soziale Herkunft in Wirtschaft, Politik, Justiz und Wissenschaft [The Myth of Meritocratic Elites: Top Level Careers and Social Origins in Economy, Politics, Justice and Science]. Frankfurt/M.: Campus.

Head, S. (2011) 'The Grim Threat to British Universities', The New York Review of Books 58.

Humboldt, W. von (1956) 'Über die innere und äußere Organisation der höheren wissenschaftlichen Anstalten in Berlin' [About the Inner and Outer Organisation of the Higher Education Institutions in Berlin], in E. Anrich (ed.) Die Idee der deutschen Universität. Die fünf Grundschriften aus der Zeit ihrer Neubegründung durch klassischen Idealismus und romantischen Realismus. Darmstadt: Wissenschaftliche Buchgesellschaft, pp. 375-86.

Humboldt, W. von (1960) 'Theorie der Bildung des Menschen' [Theory of Bildung of Man], in: A. Flitner and K. Giel (eds) Wilhelm von Humboldt. Werke in fünf Bänden, Bd. I. Darmstadt: Wissenschaftliche Buchgesellschaft, pp. 234-40.

Humboldt, W. von (2008) 'Über die Bedingungen, unter denen Wissenschaft und Kunst in einem Volke gedeihen' [About the Conditions under which Science and Art Flourish in a Nation], in W. von Humboldt (ed.) Schriften zur Sprache. Neu-Isenburg: Wunderkammer Verlag, pp. 916-21.

Huschke-Rhein, R. B. (1979) Das Wissenschaftsverständnis in der geisteswissenschaftlichen Pädagogik. Dilthey - Litt - Nohl - Spranger [The Notion of Science in Humane Pedagogics. Dilthey - Litt - Nohl - Spranger]. Stuttgart: Klett-Cotta.

Iggers, G. G. (1995) 'Historicism: The History and Meaning of the Term', Journal of the History of Ideas 56: 129-52.

Jarausch, K. H. (1981) 'Die neuhumanistische Universität und die bürgerliche Gesellschaft 1800-1870. Eine quantitative Untersuchung zur Sozialstruktur der Studentenschaften deutscher Universitäten' [The Neo-Humanistic University and Bourgeois Society 1800-1870. A Quantitative Analysis of the Social Structure of German Universities' Student Body], in C. 
Probst (ed.) Darstellungen und Quellen zur Geschichte der deutschen Einheitsbewegung im neunzehnten und zwanzigsten Jahrhundert, Bd. 11. Heidelberg: Winter, pp. 11-57.

Jaspers, K. (1946) Die Idee der Universität [The Idea of the University]. Berlin: Springer Verlag.

Kant, I. (1977) 'Zum ewigen Frieden. Ein philosophischer Entwurf' [Perpetual Peace. A Philosophical Sketch], in W. Weischedel (ed.) Immanuel Kant: Werke in zwölf Bänden, Bd. 11. Frankfurt/M.: Suhrkamp.

Kant, I. (2005) Der Streit der Fakultäten [The Conflict of the Faculties]. Hamburg: Felix Meiner Verlag.

Kocka, J. (1990) 'Veränderungen in der Geschichtswissenschaft. Eine "Geisteswissenschaft"?' [Changes in History. A 'Human Science'?], in W. Prinz and P. Weingart (eds) Die sog. Geisteswissenschaften. Innenansichten. Frankfurt/M.: Suhrkamp, pp. 134-7.

Ladenburg, A. (1912) Lebenserinnerungen [Memoirs]. Breslau: Trewendt \& Granier.

Lepenies, W. (2006) The Seduction of Culture in German History. Princeton: Princeton University Press.

Livingstone, D. N. (2007) 'Science, Site and Speech: Scientific Knowledge and the Spaces of Rhetoric', History of the Human Sciences 20(2): 71-98.

Lundgreen, P. (1983) 'Differentiation in German Higher Education', in K. H. Jarausch (ed.) The Transformation of Higher Learning. 1860-1930. Expansion, Diversification, Social Opening and Professionalization in England, Germany, Russia and the United States. Stuttgart: Ernst Klett, pp. 149-79.

Lundgreen, P. (2009) Das Personal an den Hochschulen in der Bundesrepublik Deutschland 1953-2005. Datenhandbuch zur deutschen Bildungsgeschichte, Bd. 10 [Personnel at the Universities in the Federal Republic of Germany 1953-2005. Data Handbook for German History of Education, Vol. 10]. Göttingen: Vandenhoeck \& Ruprecht.

Marquard, O. (1986) 'Über die Unvermeidlichkeit der Geisteswissenschaften' [About the Inevitability of Human Sciences], in O. Marquard (ed.) Apologie des Zufälligen. Philosophische Studien. Stuttgart: Reclam, pp. 98-116.

McClelland, C. E. (1980) State, Society, and University in Modern Germany 1700-1914. Cambridge: Cambridge University Press.

McClelland, C. E. (1983) 'Professionalization and Higher Education in Germany', in K. H. Jarausch (ed.) The Transformation of Higher Learning 1860-1930. Expansion, Diversification, Social Opening and Professionalization in England, Germany, Russia and the United States. Stuttgart: Ernst Klett, pp. 306-20.

McLennan, G. (1998) 'Sociology and Cultural Studies: Rhetorics of Disciplinary Identity', History of the Human Sciences 11(3): 1-17.

Muhlack, U. (1990) 'Bildung zwischen Neuhumanismus und Historismus' [Bildung between neo-Humanism and Historicism], in R. Koselleck (ed.) Bildungsbürgertum im 19. Jahrhundert. Teil II: Bildungsgüter und Bildungswissen. Stuttgart: Klett-Cotta, pp. 80-105. 
Müller-Solger, H. and Gieseke, L. (1977) Zu den Zukunftsperspektiven des wissenschaftlichen Nachwuchses in der Germanistik [Future Perspectives of Junior Scientific Staff of German studies], Mitteilungen des Deutschen Germanisten-Verbandes 24: 3-9.

Nida-Rümelin, J. (2003) Zur Zukunft der Geisteswissenschaften. Eine humanistische Perspektive [The Future of the Humanities. A Humanistic Perspective], in European Institute for International Affairs. Heidelberg.

Observer (2010) 'Don't Ditch Arts Funding in Favour of Science. It's Vital to our Society', The Observer. London.

Oehler, C. (1998) 'Die Hochschulentwicklung nach 1945' [Tertiary Education Development after 1945], in C. Führ and C.-L. Furck (eds) Handbuch der deutschen Bildungsgeschichte, Bd. 5/1. München: C.H. Beck, pp. 412-46.

Picht, G. (1964) Die deutsche Bildungskatastrophe. Analyse und Dokumentation [The German Catastrophe of Bildung. Analysis and Documentation]. Olten: Walter-Verlag.

Rickert, H. (1902) Die Grenzen der naturwissenschaftlichen Begriffsbildung. Eine logische Einleitung in die historischen Wissenschaften [The Limits of Concept Formation in Natural Sciences. A Logical Introduction into the Historical Sciences]. Tübingen, Leipzig: J.C.B. Mohr.

Rickert, H. (1926) Kulturwissenschaft und Naturwissenschaft [Cultural Science and Natural Science]. Tübingen: Mohr.

Ringer, F. K. (1989) 'Bildung: The Social and Ideological Context of the German Historical Tradition', History of European Ideas 10: 193-202.

Ringer, F. K. (1990) The Decline of the German Mandarins: the German Academic Community, 1890-1933. Lebanon, New England: University Press of New England.

Ritter, J. (1974) 'Die Aufgabe der Geisteswissenschaften in der modernen Gesellschaft' [The Purpose of Human Sciences in the Modern Society], in J. Ritter (ed.) Subjektivität. Sechs Aufsätze. Frankfurt/M.: Suhrkamp.

Röther, K. (1980) Die Germanistenverbände und ihre Tagungen. Ein Beitrag zur germanistischen Organisations- und Wissenschaftsgeschichte [The Associations of Scholars of German Studies and their Congresses. A Contribution to the Organisational and Scientific History of German Studies]. Köln: Pahl-Rugenstein Verlag.

Rüegg, W. (2004) 'Theologie und Geisteswissenschaften' [Theology and Geisteswissenschaften], in W. Rüegg (ed.) Geschichte der Universität in Europa. Bd. III: Vom 19. Jahrhundert zum Zweiten Weltkrieg (1800-1945). München: C. H. Beck, pp. 325-78.

Salter, B. and Tapper, T. (2002) 'The External Pressure on the Internal Governance of Universities Higher', Education Quarterly 56: 245-56.

Schleiermacher, F. (1956) 'Gelegentliche Gedanken über Universitäten im deutschen Sinn, nebst einem Anhang über neu zu errichtende' [Occasional Thoughts on Universities in the German Sense, With an Appendix Regarding a University Soon to be Established], in E. Anrich (ed.) Die Idee der deutschen Universität. Die fünf Grundschriften aus der Zeit ihrer Neubegründung durch klassischen Idealismus und romantischen Realismus. Darmstadt: Wissenschaftliche Buchgesellschaft, pp. 219-93. 
Schnädelbach, H. (1983) Philosophie in Deutschland 1831-1933 [Philosophy in Germany 1831-1933]. Frankfurt/M.: Suhrkamp.

Schücking, L. L. (1961) Soziologie der literarischen Geschmacksbildung [Sociology of Literary Formation of Taste]. Bern, München: Francke.

Schwartz, S. (2011) 'Not By Skills Alone', Times Higher Education.

Simmel, G. (1923) Die Probleme der Geschichtsphilosophie. Eine erkenntnistheoretische Studie [Problems of History of Philosophy. An Epistemological Study]. München: Duncker \& Humblot.

Snow, C. P. (2008) The Two Cultures. Cambridge: Cambridge University Press.

Sorkin, D. (1983) 'Wilhelm Von Humboldt: The Theory and Practice of Self-Formation (Bildung)', Journal of the History of Ideas 44: 55-73.

Stooß, F. (1991) 'Berufsaussichten für Germanisten und neue Studiengänge' [Professional Outlook für Scholars of German Studies and new Degree Courses], in J. Janota (ed.) Kultureller Wandel und die Germanistik in der Bundesrepublik. Vorträge des Augsburger Germanistentags 1991. Tübingen: Max Niemeyer Verlag, pp. 171-5.

Titze, H. (1987) Das Hochschulstudium in Preußen und Deutschland 1820-1944. Datenhandbuch zur deutschen Bildungsgeschichte, Bd. 1,1 [University Education in Prussia and Germany 1820-1944. Data Handbook for German History of Education, Vol. 1,1]. Göttingen: Vandenhoeck \& Ruprecht.

Titze, H. (1995) Wachstum und Differenzierung der deutschen Universitäten 1830-1945. Datenhandbuch zur deutschen Bildungsgeschichte, Bd. 1,2 [Growth and Differentiation of German Universities 1830-1945. Data Handbook of German History of Education, Vol. 1,2]. Göttingen: Vandenhoeck \& Ruprecht.

Veit-Brause, I. (2001) 'Scientists and the Cultural Politics of Academic Disciplines in Late 19thCentury Germany: Emil Du Bois-Reymond and the Controversy over the Role of the Cultural Sciences', History of the Human Sciences 14(4): 31-56.

von Ferber, C. (1956) Die Entwicklung des Lehrkörpers der deutschen Universitäten und Hochschulen 1864-1954 [The Development of Academic Staff of German Universities and Tertiary Institutions 1864-1954]. Göttingen: Vandenhoeck \& Ruprecht.

Voßkamp, W. (1990) 'Literaturwissenschaft als Geisteswissenschaft. Thesen zur Geschichte der deutschen Literaturwissenschaft nach dem zweiten Weltkrieg' [Literary Studies as Human Sciences. Theses on the History of German Literary Studies after the Second World War], in W. Prinz and P. Weingart P. (eds) Die sog. Geisteswissenschaften. Innenansichten. Frankfurt/M.: Suhrkamp, pp. 240-7.

Weber, M. (1922) 'Wissenschaft als Beruf' [Science as a Vocation], in M. Weber (ed.) Gesammelte Aufsätze zur Wissenschaftslehre. Tübingen: J. C. B. Mohr, pp. 524-55.

Wehler, H.-U. (1973) Geschichte als historische Sozialwissenschaft [History as Historial Social Science]. Frankfurt/M.: Suhrkamp.

Weingart, P., et al. (1991) Die sog. Geisteswissenschaften: Außenansichten [The So-Called Human Sciences. Exterior Views]. Frankfurt/M.: Suhrkamp. 
Windelband, W. (1894) Geschichte und Naturwissenschaft. Rede beim Stiftungsfest der KaiserWilhelms-Universitaet Strassburg, 1. Mai 1894 [History and Natural Sciences. Rectoral Address at the Kaiser-Wilhelms-Universitaet in Strassburg, 1st May 1894]. Strassburg: Druck von Heitz.

Windelband, W. (1921) Präludien. Aufsätze und Reden zur Philosophie und ihrer Geschichte, 2 Bde [Preludes. Articles and Speeches about Philosophy and its History, 2 vols.]. Tübingen: Mohr.

Windolf, P. (1997) Expansion and Structural Change: Higher Education in Germany, United States and Japan 1870 -1990. Boulder: Westview.

Wissenschaftsrat [The German Council of Sciences and Humanities] (2006) 'Empfehlungen zur Entwicklung und Förderung der Geisteswissenschaften in Deutschland'. Berlin.

Wissenschaftsrat [The German Council of Sciences and Humanities] (2008) 'Empfehlungen zur Qualitätsverbesserung von Lehre und Studium'. Berlin. 